KOŚCIÓŁ I PRAWO 10(23) 2021, nr 2, s. 181-194

DOI: https://doi.org/10.18290/kip21102.12

\author{
Ambroży Skorupa
}

\title{
KANONICZNO-PRAWNE OBSZARY DIALOGU W ŻYCIU ZAKONNYM
}

\section{WPROWADZENIE}

Osoba zakonna zobowiązana jest do życia we wspólnocie. Życie cenobitalne stanowiło od początku pewną koncepcję dojścia do świętości. Pierwotni chrześcijanie trwali na modlitwie, wszystko mieli wspólne, podejmowali także wspólne dzieła miłosierdzia (Dz 2,42; 4,32n.) $)^{1}$. Z czasem wspólnota świętych przybierała różne formy. Możemy mówić o wspólnocie Kościoła w ogóle. Wtedy należy patrzeć na gminy chrześcijańskie szukające $\mathrm{w}$ dialogu porozumienia, ujednolicenia sposobu postępowania. Wyraźnym przykładem takich dążeń są ustalenia Soboru Jerozolimskiego odnośnie do relacji pomiędzy judeochrześcijanami i poganochrześcijanami. Rozwiązaniem tej sytuacji był dialog pomiędzy stronami, które prezentowały różne poglądy (Dz 11; 15).

$\mathrm{Z}$ czasem we wspólnocie chrześcijan powstawały różne formy życia. $\mathrm{Pu}$ stelnicy oraz mnisi żyjący w zakładanych przez Pachomiusza klasztorach, wskazują na potrzebę kształtowania się życia wspólnotowego. Różne były

KS. DR HAB. AmBRoży SkorUPA - Katedra Historii, Norm Ogólnych, Prawa Sakramentów i Instytutów Życia Konsekrowanego, Wydział Prawa, Prawa Kanonicznego i Administracji, Katolicki Uniwersytet Lubelski Jana Pawła II; adres do korespondencji: Al. Racławickie 14, 20-950 Lublin, Polska; e-mail: ambrozy.skorupa@kul.pl; https:// orcid.org/0000-0002-1849-8420

${ }^{1}$ Pismo Święte Starego i Nowego Testamentu, Pallottinum, Poznań 2003. 
koncepcje wspólnoty u poszczególnych założycieli zakonów². Władza kościelna także angażowała się w budowanie wewnętrznej struktury klasztorów. Jedni widzieli dominującą rolę przełożonego, inni akcentowali potrzebę dialogu pomiędzy braćmi i siostrami. Ten wymiar dialogu w życiu zakonnym został także podjęty na Soborze Watykańskim II i zawarty w dokumentach Kościoła ${ }^{3}$.

Dialog należy rozumieć w sensie ogólnym, jako spotkanie osób lub grup społecznych o różnych dążeniach. Jego celem jest wzajemna wymiana własnych przekonań lub współdziałanie według określonego programu. W sensie socjologicznym na dialog składają się trzy elementy: wewnętrzne uwarunkowania osób, reprezentowane przez nich wartości oraz środki przekazywania myśli. Prowadzenie dialogu powinno opierać się na godności oraz wolności osobistej każdej osoby ludzkiej, obowiązku dążenia do poznania prawdy oraz wzajemnej tolerancji przy dążeniu do wzbogacenia własnych poglądów [Łukaszyk 1985, 1259-261].

Dialog w Kościele, a więc i w instytutach zakonnych, ma także wymiar prawny i dotyczy zarówno przełożonych, jak również podwładnych. Prawny kształt tego dialogu będzie treścią niniejszego artykułu.

$\mathrm{Na}$ początku 2017 r. Kongregacja Instytutów Życia Konsekrowanego i Stowarzyszeń życia Apostolskiego wydała wytyczne/ukierunkowania pt. „Młode wino, nowe bukłaki”, w których podkreśla się elementy dialogu we

${ }^{2}$ Zob. Reguła św. Benedykta 3,1: Reguła św. Benedykta. Przekład A. Świderkówna, Wydawnictwo Benedyktynów, Kraków 2010 [Dąbek 2009, 24-25]; Reguła św. Franciszka 4-7, w: Pisma św. Franciszka i św. Klary, Ojcowie Kapucyni, Warszawa 1992, s. 3538; Reguła św. Klary 4, 10, w: Pisma św. Franciszka i św. Klary, s. 162-69.

${ }^{3}$ Sacrosanctum Concilium Oecumenicum Vaticanum II, Constitutio dogmatica de Ecclesia Lumen gentium (21.11.1964), AAS 57 (1965), s. 5-75, nr 14-16, 22-23, 36; Tenże, Constitutio pastoralis de Ecclesia in mundo huius temporis Gaudium et spes (07.12. 1965), AAS 58 (1966), s. 1025-115, nr 9, 21, 25, 28, 43, 74, 76; Tenże, Declaratio de libertate religiosa Dignitatis humanae (07.12.1965), AAS 58 (1966), s. 929-46, nr 15; Tenże, Decretum de apostolatu laicorum Apostolicam actuositatem (18.11.1965), AAS 58 (1966), s. 837-64, nr 12, 14; Tenże, Decretum de accommodata renovatione vitae religiosae Perfectae caritatis (28.10.1965), AAS 58 (1966), s. 702-12 [dalej: PC], nr 4, 14, 23; Paulus PP. VI, Motu proprio Ecclesiae sanctae (06.08.1965), AAS 58 (1966), s. 757-87 [dalej: ES], nr II 3, 1825-829; Paulus PP. VI, Adhortatio apostolica de religiosa vita secundum Concilii Oecumenici Vaticani II renovanda praeceptiones Evangelica testificatio (29.07.1971), AAS 63 (1971), s. 497-526, nr 25, 28; Kongregacja Instytutów Życia Konsekrowanego i Stowarzyszeń Życia Apostolskiego, Instrukcja Faciem tuam Domine requiram, Libreria Editrice Vaticana, Watykan 2008 [dalej: FT], nr 20, 25. 
wspólnocie zakonnej ${ }^{4}$. Zasadniczo w Kodeksie Prawa Kanonicznego z 1983 r. ${ }^{5}$ te elementy są zawarte, jednak sposób ich realizacji powinien być dostosowany do mentalności współczesnego człowieka. Połączenie regulacji prawnych oraz propozycji nowych form realizacji dialogu będzie przedmiotem niniejszego artykułu.

\section{DIALOG NA ETAPIE FORMACJI}

Sobór Watykański II podkreśla, że przystosowana odnowa życia zakonnego tylko wtedy będzie skuteczna i tylko wtedy przyniesie owoce, kiedy będą w nią zaangażowani wszyscy członkowie instytutu (PC 4). W dokumencie dostrzega się, że zarówno w procesie formacji, jak i w jej założeniach brakuje integralności między elementami teologicznymi i antropologicznymi. Brak tej integracji uniemożliwia dialog $\mathrm{w}$ procesie wzrastania humanistycznego i duchowego. Należy odejść od przekonania, że te dwa wymiary będą funkcjonowały autonomicznie. Dialog antropologiczny i teologiczny jest podjęciem wezwania soborowego o dialogu pomiędzy kulturami, jak również pomiędzy pokoleniami we wspólnocie zakonnej (MW 14).

Dialog jest wpisany w strukturę życia zakonnego. Można na początku przyjąć założenie, że zdolność do jego prowadzenia jest konieczna, aby dopuścić do życia w instytucie. Ustawodawca w kan. 642 KPK/83 wymaga, aby kandydat miał odpowiednie przymioty dojrzałości, cechy charakteru, które sprawiają, że jest zdolny do życia właściwego instytutowi. Zdolność do życia we wspólnocie, zdolność do dialogu oraz zdolność do współpracy wydaje się tu podstawą do efektywnej formacji zakonnej w nowicjacie. To we wspólnocie z mistrzem nowicjatu oraz pozostałymi nowicjuszami przebiega cały proces poszczególnych nowicjuszy (kan. 652 § 3) [Rincón 2007, 853]. Właśnie dialog jest podstawą tej wspólnoty oraz współpracy. Niewłaściwa jest postawa, kiedy osoby mające władzę w instytucie wydają polecenia, natomiast nowicjusze są biernymi wykonawcami owych poleceń.

\footnotetext{
${ }^{4}$ Kongregacja Instytutów Życia Konsekrowanego i Stowarzyszeń Życia Apostolskiego, Młode wino, nowe bukłaki. Życie konsekrowane od Soboru Watykańskiego II $i$ wyzwania nadal otwarte. Ukierunkowania, Wydawnictwo Sióstr Loretanek, Warszawa 2017 [dalej: MW].

${ }^{5}$ Codex Iuris Canonici auctoritate Ioannis Pauli PP. II promulgatus (25.01.1983), AAS 75 (1983), pars II, s. 1-317; tekst polski: Kodeks Prawa Kanonicznego, przekład polski zatwierdzony przez Konferencję Episkopatu, Pallottinum, Poznań 1984 [dalej: $\mathrm{KPK} / 83]$.
} 
Podobnie ta kwestia jawi się w obszarze formacji czasowej. Profes czasowy powinien wykazać zdolność do dialogu. Szczególnie ten rodzaj komunikacji powinien dotyczyć relacji z przełożonymi oraz osobami odpowiedzialnymi za formację ${ }^{6}$. Tylko szczera, autentyczna współpraca pozwoli osiągnąć dojrzałość w życiu zakonnym. Dlatego od osób odpowiedzialnych za formację ustawodawca wymaga takich cech jak znajomość psychiki młodych ludzi, a także ich sposobu bycia, aby nawiązać z nimi konstruktywny dialog pozwalający na osiągnięcie dojrzałości wymaganej do złożenia profesji wieczystej, poświęcenia się Panu Bogu w życiu zakonnym w danym instytucie (PI 60).

\section{DIALOG W ŻYCIU WSPÓLNOTOWYM}

Zakonnik ma obowiązek przebywać w domu zakonnym zachowując życie wspólne. Takim elementem życia wspólnotowego jest właśnie wzajemny dialog. Realizuje się on w życiu braterskim we wspólnocie ${ }^{7}$. Jeśli chodzi o instytucjonalne jego formy, to w każdym domu zakonnym wspólnota spotyka się na Eucharystii, która jest jej centrum (kan. 608, $663 \S 2$ ), posiłkach oraz rekreacji [Bilska 2013, 124-34]. Tak ułożone funkcjonowanie wspólnoty pozwala i zobowiązuje do zachowania postawy dialogu i wzajemnego zrozumienia. Dlatego zgodnie z regulacjami kan. 665 zakonnicy są zobowiązani przebywać we własnym domu zakonnym i nie można go opuszczać bez zgody przełożonego. Ratio legis takiej normy jest właśnie życie wspólne. Według instrukcji Faciem tuam Domine requiram, ta obecność w życiu wspólnym profesa jest obligatoryjna i ma wymiar aktywności we wspólnocie [Szewczul 2010, 75-77]. Także papież Jan Paweł II w adhortacji apostolskiej Vita consecrata ${ }^{8}$ wskazuje na konieczność dialogu w życiu wspólnym, w którym dojrzewa każde powołanie zakonne. W tym dialogu uczestniczą osoby zakonne piastujące różne urzędy i funkcje, jak ci, którzy

\footnotetext{
${ }^{6}$ Congregatio pro Institutis Vitae Consecratae et Societatibus Vitae Apostolicae, Normae directivae de institutione in religiosis institutis Potissimum institutioni (02.02.1990), AAS 82 (1990), s. 470-532 [dalej: PI], nr 31, 51.

${ }^{7}$ Congregazione per gli Istituti di Vita Consacrata e le Società di Vita Apostolica, La vita fraterna in comunità Congregavit nos in unum Christi amor (02.02.1994), Città del Vaticano, Libreria Editrice Vaticana 1994, nr 5-6, 12.

${ }^{8}$ Ioannes Paulus PP. II, Adhortatio apostolica post-synodalis de vita consecrata eiusque missione in Ecclesia ac mundo Vita consecrata (25.03.1996), AAS 88 (1996), s. 377-486 [dalej: VC].
} 
w danym momencie żadnych urzędów nie pełnią. Dialog we wspólnocie zakonnej jest także okazją do dzielenia się życiowym doświadczeniem. Dlatego ważne jest podkreślenia szacunku do osób starszych, które mogą dzielić się swoim doświadczeniem, a ich wkład w życie wspólnoty jest nieoceniony (VC 43).

Ważnym, a zarazem delikatnym uprawnieniem wspólnoty jest jej zaangażowanie $\mathrm{w}$ decyzję o wyborze kapelana i spowiednika. Ustawodawca wymaga, aby przed zaakceptowaniem kapłanów wykonujących te funkcje w dialogu uczestniczyła cała wspólnota (kan. 630 § 3, 567 § 2).

Podkreślając aktywność życia wspólnoty w dialogu trzeba bardzo jasno zaznaczyć, że dialog ten nie może ograniczać ani zastępować władzy przełożonego. To przełożeni są odpowiedzialni za realizację wymagań dialogu, w dialogu każdego należy wysłuchać, każdy powinien w nim aktywnie uczestniczyć (FT 19). Jednak należy pamiętać, że dialog w życiu zakonnym nie jest rozstrzygający. To do władzy należy ostatnie słowo, czyli podejmowanie decyzji. Władza także ma obowiązek zadbać o realizację podjętych decyzji (FT 20).

Wytyczne Kongregacji zwracają także uwagę na relacje przełożony podwładny. Obydwie strony dialogu stanowią wspólnotę. Dykasteria ta zauważa, że w relacjach pomiędzy władzą a podwładnymi brakuje ewangelicznego fundamentu braterstwa. Jedną z propozycji łagodzenia tego konfliktu może być integralna formacja. Zarówno przełożeni, jak i podwładni powinni słuchać tych samych wykładów, konferencji. Niezbyt skuteczne wydają się praktyki kursów dla przełożonych czy ekonomów. Wspólnota składa się z przełożonych, podwładnych czy innych osób pełniących określone funkcje we wspólnocie, których sprawowanie ma duży wpływ na funkcjonowanie wspólnoty [Florek 2017]. Wspólna formacja może przyczynić się do budowania braterstwa w wymiarze ludzkim. Brak tego braterstwa jest wymieniony jako jedna z głównych przyczyn kryzysów i odejść (MW 24).

Takie rozumienie dialogu wyraźnie prowadzi do określonego celu. Dialog nie jest instytucją samą w sobie. Wspólnota zakonna nie powstaje dla dialogu. Dialog jest pomocnym środkiem do osiągnięcia celu (FT 20), a celem każdej wspólnoty zakonnej i każdej osoby zakonnej jest dawanie świadectwa życia konsekrowanego ożywianego modlitwą i pokutą. Następnie każda wspólnota zakonna powinna dawać przykład komunii w Kościele. Jest ona cennym świadectwem dla całego Kościoła (VC 45), dlatego życie 
zakonne jest tak przez Kościół cenione i ciągle aktualne we wszystkich jego formach.

\section{PODEJMOWANIE DECYZJI - KAPITUŁY}

Kolejnym ważnym obszarem dialogu w życiu zakonnym jest kapituła. Początki kapituł generalnych sięgają już X w. w klasztorach kongregacji w Cluny. Według obowiązującego ustawodawstwa wyróżnia się różne stopnie kapituł w instytutach zakonnych. Ustawodawca w KPK/83 wymienia jedynie kapitułę generalną. Wskazuje także na możliwość istnienia innych kapituł, które funkcjonują na wzór kapituły generalnej. Celem kapituły generalnej jest zebranie przedstawicieli całego instytutu, aby podejmowali decyzje dotyczące najważniejszych spraw w instytucie (kan. 631). Takie decyzje podejmuje się $\mathrm{w}$ dialogu, który w tym przypadku ma bardzo praktyczny wymiar. Sam skład kapituły generalnej ma zostać szczegółowo uregulowany w konstytucjach (FT 20). Jednak KPK/83 wskazuje, że powinny być dwie grupy reprezentujące instytut - mianowicie członkowie $\mathrm{z}$ wyboru i członkowie z urzędu. Niekiedy konstytucje zawierają obligatoryjną proporcję pomiędzy uczestnikami z urzędu i uczestnikami z wyboru. Wśród tych regulacji spotykamy instytuty, w których podczas kapituły generalnej powinno być więcej członków $\mathrm{z}$ wyboru od tych $\mathrm{z}$ urzędu, jak również spotykamy regulacje, w których te proporcje powinny być rozłożone po połowie. Taka konstrukcja zapewnia udział wszystkich członków instytutu w procesie dialogu. Wyraża się on w fakcie, że wszyscy profesi uczestniczą w wyborach z prawem głosu czynnego. Od regulacji w kodeksie fundamentalnym zależy, czy głos bierny mają tylko profesi wieczyści, czy także profesi czasowi. KPK/83 pozwala na przyjęcie różnych rozwiązań. W tym kontekście ważne jest dla instytutu, aby członkowie uczestniczyli w jego życiu, podejmowali dyskusje, dzielili się swoją wiedzą i doświadczeniem. Kapituła, jako znak jedności i miłości całego instytutu, jest znakomitą okazją do podjęcia aktywności na rzecz instytutu. Jest to bardzo ważne w kontekście zadań i kompetencji, jakie podejmuje kapituła. Ustawodawca kościelny zalicza do nich, zgodnie z kan. 631 i 587, uchwalanie konstytucji oraz wprowadzanie zmian zgodnie z przepisami. Jest to istotne, ponieważ można ustalić kwalifikowaną większość do uchwalenia konstytucji i wprowadzenia w nich zmian. Podjęcie takiej decyzji wymaga autentycznego po- 
rozumienia i osiągnięcia konsensusu. Kolejnym elementem ważnym dla braci czy sióstr w instytucie jest wybór najwyższego przełożonego. Dokonuje się to także na kapitule generalnej, zgromadzeniu reprezentującym cały instytut, często o charakterze międzynarodowym. W tym kontekście widzimy konieczny dialog, w którym uczestniczą osoby z różnych krajów i kultur. Tematyką podejmowaną podczas kapituł generalnych jest także troska o duchowe dziedzictwo instytutu oraz przystosowana do współczesności odnowa (PC 1; ES II 6, 25). Duchowe dziedzictwo (patrimonium) jest wspólne dla każdego instytutu i pochodzi od założyciela. To duchowe dziedzictwo należy rozeznawać i odczytywać stosownie do potrzeb czasu. W procesie przystosowanej odnowy należy uszanować elementy niezmienne w życiu zakonnym, do których należą: Ewangelia i zamiary założycieli oraz elementy, które należy aktualizować, czyli sposoby realizacji zamiarów założycieli w zmieniających się warunkach świata i ludzkiej mentalności. Życzeniem ustawodawcy jest więc, aby ten proces dokonywał się w dialogu z udziałem reprezentantów całego instytutu. Jak wspomniano wcześniej, sama kapituła generalna reprezentuje cały instytut, jednak nie tylko jej uczestnicy mają prawo uczestniczyć w tym dialogu. Zgodnie z kan. 632 i przepisami prawa własnego do kapituły swoje postulaty i sugestie mogą zgłaszać prowincje, wspólnoty domowe oraz poszczególni członkowie instytutów. Celem troski o skuteczność takiej aktywności należy ustalić zasady, według których można takie postulaty, wskazania i sugestie przedstawiać kapitule, co zapewnia, że postulaty będą rzeczywiście przemyślane i będą mogły być rozpatrzone przez kapitułę. Takie zasady można ustalić w różnych zbiorach prawa własnego - statutach, typikach, zwyczajnikach, regulaminach czy dyrektorium, jednak bardzo ważne wydaje się, aby takie działanie stało się praktyką w instytucie. W ten sposób tworzy się pewna kultura dialogu, rzeczywiście istniejąca w instytucie. Oczywiście celem każdego dialogu jest podjęcie decyzji. Kapituła generalna ma obowiązek i zadanie przyjąć rozstrzygnięcia podjęte taką drogą. Czas trwania kapituły jest ustalony. KPK/83 nie przewiduje kapituł permanentnych (kan. 631) [Zubert 1990, 92]. Kapituła funkcjonuje tylko i wyłącznie w czasie swojego urzędowania - od zwołania zgodnie z konstytucjami aż do urzędowego zamknięcia.

Kapituła generalna jest $\mathrm{w}$ tym czasie urzędowania najwyższą władzą i zajmuje się najwyższą władzą w instytucie, ale nie jest jedyną. Władza kapituły generalnej nie dotyczy tych obszarów, które zgodnie z przepisami 
powszechnego prawa Kościoła, jak i konstytucji są powierzone przełożonym, takie jak: przyjęcie do nowicjatu, dopuszczenie do profesji, dymisoria dla kandydatów do sakramentu święceń, udzielenie indultu eksklaustracyjnego, wyrażenie zgody na pobyt poza domem zakonnym, odpowiedzialność majątkowa. Taka konstrukcja z kolei pozwala uchronić instytut przed zbytnią dominacją ze strony kapituły generalnej. W podobnym kontekście należy odczytywać zapis, że kapituła generalna załatwia ważniejsze sprawy instytutu. Sprawy mniejszej wagi należy powierzyć innym organom kolegialnym lub przełożonym. Jeśli chodzi o sprawy wspólnoty domowej czy prowincjalnej, wówczas takie sprawy dotyczące tych jednostek powinny być załatwione przez kapitułę prowincjalną lub wspólnotę domową. W tym zapisie - „załatwia ważniejsze sprawy instytutu” - widzimy realizację zasadny pomocniczości wewnątrz samego instytutu. Tak skonstruowany dialog pozwala uniknąć dominacji danej części instytutu nad inną. Mogą się bowiem zdarzyć prowincje liczebniejsze, które mogą mieć pokusę narzucania rozwiązań, które mogą być skuteczne w jednym kraju, a w innych te metody takie nie będą. Dlatego zasada pomocniczości w tym kontekście sprzyja życiu wspólnotowemu w dialogu i wzajemnym zrozumieniu.

Mając na uwadze powagę urzędu kapituły oraz odpowiedzialność za podjętą decyzję, Stolica Apostolska zwraca uwagę na odpowiednie procedury jej funkcjonowania. KPK/83 wyraźnie reguluje, że kapituła jest reprezentacją całego instytutu. Dlatego należy uaktualnić procedury wyborów, określenia reprezentacji z urzędu, aby wymóg prawa był zachowany. Niewłaściwą sytuacją jest hegemonia jednej kultury albo utrzymywanie ograniczeń pokoleniowych. Uzasadnionym wydaje się postulat, aby procedury gwarantowały transparentność i zarazem były na tyle elastyczne, by gwarantowały szersze przedstawicielstwo, które pozwoli kapitule podjąć dalekowzroczne decyzje. Dlatego można przewidzieć uczestników kapituły generalnej z głosem opiniującym, przedstawienie punktu widzenia przedstawicieli młodszych jednostek administracyjnych instytutu (MW 49).

Kapituły prowincjalne obecne w praktyce wielu instytutów mają na celu rozwój kultury dialogu wewnątrz instytutów. W tym kontekście możemy mówić o podwójnym wymiarze dialogu. Bowiem kapituła prowincjalna umacnia dialog wewnątrz tej prowincji lub innej części z prowincją zrównaną oraz wprowadza dialog międzynarodowy, ogólnoinstytutowy. Kapituła prowincjalna jest reprezentacją prowincji, która może przedstawić swoje postulaty kapitule generalnej. Kolejnym polem łączności w instytucie jest 
rozpoznanie uchwał kapituły generalnej i przedstawienie sposobów ich realizacji w danej jednostce administracyjnej z uwzględnieniem miejscowych warunków i mentalności wiernych. Wreszcie łączność ta dokonuje się przez obowiązek zatwierdzenia uchwał kapituły prowincjalnej przez przełożonego najwyższego.

Kolejnym obszarem dialogu są kapituły domowe. W instytutach hierarchicznych mogą one być praktyką obowiązkową. Kapituła domowa może mieć różne kompetencje. Nie jest ona obligatoryjna, jednak w wielu regulacjach prawa własnego spotkanie we wspólnocie wszystkich profesów co określony czas jest obowiązkowe. Podczas takich spotkań, niekiedy zwanych kapitułami, omawiane są sprawy wspólnoty, przedstawiane są opinie poszczególnych jej członków.

Osobnym obszarem dialogu są kapituły w klasztorach autonomicznych. KPK/83 nie reguluje kwestii funkcjonowania klasztorów mniszych. Tylko dwa kanony, a mianowicie 614 i 615, zawierają regulacje dotyczące klasztorów niezależnych. Niemniej jednak kapituły w tych klasztorach funkcjonują i zachowały swoją władzę. Szczegółowe regulacje znajdują się w konstytucjach poszczególnych zakonów oraz statutach klasztorów. Z zasady w kapitule klasztorów uczestniczą wszyscy mnisi lub mniszki, którzy złożyli profesję wieczystą. Kapituły w klasztorach niezależnych mają podobne kompetencje jak kapituły generalne w instytutach hierarchicznych. $\mathrm{Na}$ kapitule wyborczej w klasztorze wybiera się przełożonego klasztoru. Oznacza to, że przełożeni klasztorów niezależnych również są ustanawiani przez kanoniczny wybór (kan. $625 \S 2$ ) [Chiappetta 2011, 746-48]. W niektórych klasztorach niezależnych wyborom przełożonego lub przełożonej przewodniczy biskup diecezjalny (kan. 625). Swoje zadanie biskup może wykonać osobiście lub zlecić delegatowi. Podczas innych kapituł załatwia się ważniejsze sprawy podane $\mathrm{z}$ odpowiednim wyprzedzeniem przez przełożonego. Kapituły klasztorów niezależnych, zgodnie z konstytucjami, podejmują decyzje personalne takie jak: dopuszczenie do nowicjatu, profesji czasowej lub uroczystej oraz - zgodnie z kan. $684 \S 2$ - do ważności kapituła klasztoru wyraża zgodę na przyjęcie profesa po ślubach wieczystych $\mathrm{z}$ innego instytutu do swojego klasztoru na stałe. Podsumowując, kapituły klasztorów niezależnych podejmują decyzje $\mathrm{w}$ sprawach personalnych ze względu na fakt, że z danym nowicjuszem, profesem czasowym czy mającym być dopuszczonym do profesji wieczystej będą żyć wszyscy członkowie klasztoru danego zakonu. Dlatego taka decyzja jest podejmowana przez 
wspólnotę. Taka też jest racja regulacji zawartej w kan. 684 § 3 .

Kapituły są więc obszarem dialogu we wszystkich formach życia zakonnego. Stosownie do tradycji instytutu różne są regulacje dotyczące sposobu funkcjonowania kapituły, proporcji uczestników z urzędu do delegatów z wyboru, formy przedstawiania postulatów, itp. Ważne też jest to, że podczas kapituły decyzja zapada określoną prawem większością głosów (absolutną bądź kwalifikowaną). W głosowaniu, zabieraniu głosu w dyskusji, wszyscy są równi i zobowiązani, aby zgodnie z sumieniem, w sposób odpowiedzialny i mający na celu dobro instytutu, zabierać głos w dyskusji i głosować. Podjęte decyzje i przyjęte na kapitule normy wszyscy powinni zachowywać (kan. 631) [Rincón 2007, 835]. Normy te są efektem decyzji poprzedzonej dyskusją, dialogiem i przyjętym konsensusem wyrażonym w głosowaniu.

\section{DIALOG W POSŁUDZE PRZEŁOŻONEGO}

Prawo kościelne wymaga od przełożonych zakonnych przewodniczenia w dialogu wspólnoty. To działanie jest wymagane przed powołaniem na urząd, jak również w trakcie jego sprawowania. KPK/83 przewiduje dwie formy powołania na urząd - wybór lub nominacja. W każdej z tych form następuje dialog na różnych szczeblach - pomiędzy przełożonymi i podwładnymi i dokonuje się przez aprobatę lub konsultację.

Jak wyżej wspomniano w instytutach zakonnych są dwie formy powołania na urząd - wybór i nominacja. Jeśli chodzi o wybór, to kan. 625 stanowi, że najwyższy przełożony powinien być ustanowiony przez kanoniczny wybór, który dokonuje się na kapitule generalnej zgodnie z regulacją kan. 631. Procedura tego wyboru powinna być określona w konstytucjach, jak również w regulaminie kapituły. Każdy z uczestników kapituły generalnej, jak również cały instytut są zobowiązani do aktywnego udziału w procesie rozeznawania. Współodpowiedzialność kolegium kapituły generalnej dotyczy także obowiązku poszukiwania rozwiązań alternatywnych. Pożytecznie trzeba ocenić gotowość osób zakonnych do pełnienia służby na urzędzie przełożonego. Niepokojącym zjawiskiem jest unikanie tej odpowiedzialności, odmawianie obowiązków wynikających z pełnienia urzędu (MW 51). Podobnie sprawa się ma z przełożonymi klasztorów niezależnych, gdzie wyborom przewodniczy biskup diecezjalny. Pozostali przełożeni są ustana- 
wiani zgodnie $\mathrm{z}$ przepisami prawa, jednak w taki sposób, że kiedy ma miejsce wybór, np. przez kapitułę prowincjalną czy domową, wtedy wymagana jest akceptacja, natomiast kiedy ma miejsce nominacja, wówczas jest wymagana konsultacja. Te relacje dialogu są obligatoryjne. W ten sposób realizuje się więź wspólnotowa wychodząca od podwładnych wobec kierunku przełożonych. To wspólnota, gremium uprawnione do głosowania dokonuje wyboru. Uwzględniając ten wybór i po sprawdzeniu jego legalności, kompetentna władza dokonuje zatwierdzenia wybranego, co pozwala prawomocnie objąć urząd. Taka konstrukcja pozwala na utrzymanie łączności oraz zachowanie przepisów prawa. Obowiązek czuwania spoczywa na władzy kościelnej. W kan. 625 takie zatwierdzenie przez biskupa diecezjalnego jest wymagane w przypadku wyboru najwyższego przełożonego instytutu na prawie diecezjalnym oraz przełożonego klasztoru niezależnego. Także w strukturze wewnątrz zakonnej można wprowadzić regulacje, według których przełożony najwyższy zatwierdzi wybór przełożonego prowincji lub przełożony prowincji przełożonego wspólnoty domowej.

Analogiczny cel przysługuje wymaganym w kan. $625 \S 3$ konsultacjom przeprowadzonym przez kompetentną władzę, która może mianować na urząd przełożonego. Konsultacja ta nie ogranicza władzy przełożonego w procesie swobodnego nadania urzędu. Wyniki konsultacji bowiem w żaden sposób nie ograniczają władzy przełożonego, pozwalają natomiast uzyskać właściwe rozeznanie odnośnie do wyboru kandydatów najbardziej odpowiednich.

Zarówno wybierający, jak i nominujący są związani przepisem kan. 626, w którym ustawodawca zobowiązuje do powstrzymania się od nadużyć i względów ludzkich. Trzeba mieć przed oczami tylko Boga i dobro instytutu oraz głosować i nominować tylko tych, których przed Bogiem uznają za godnych i odpowiednich. Można powiedzieć, że proces wyboru przełożonych przebiega w dialogu, który ma swoje kanoniczne standardy.

\section{ZAKOŃCZENIE}

Jednym $\mathrm{z}$ istotnych elementów życia zakonnego jest wspólnota, w której poszukuje się woli Bożej. Nie można tego czynić indywidualnie. Wspólne dążenie do Boga jest możliwe przez postawę dialogu pomiędzy zakonnikami, pomiędzy podwładnymi i przełożonymi. Okazją do tego dialogu są wspólne 
spotkania oraz wspólna posługa zgodna z charakterem danego instytutu. Tak skonstruowana wspólnota wymaga więc wzajemnego porozumienia, dialogu. Ten dialog realizowany jest nie tylko faktycznie i spontanicznie, ale także ma swoje struktury formalne. Najwyższą instytucją w każdym zgromadzeniu jest kapituła generalna, która realizuje swoje zadania właśnie we wspólnocie, współpracy i dialogu, jako reprezentacja całego instytutu. Podobnie działają kapituły w klasztorach niezależnych, prowincjach oraz domach zakonnych instytutów hierarchicznych. Także przełożeni sprawując swój urząd zobowiązani są do praktykowania dialogu, czy to ze swoją radą, czy z pozostałymi podwładnymi. Dokumenty Kościoła podkreślają wymiar antropologiczny i personalistyczny dialogu. Taka umiejętność mediacji powinna być także uwzględniona zarówno przez przełożonych, jak i podwładnych. Jednak należy zaznaczyć, że do sprawujących posługę władzy należy ostatnie słowo, decyzja i troska o jej wykonanie. Posługa odpowiedzialnych za formację także odbywa się $\mathrm{w}$ atmosferze dialogu z osobami na etapie formacji podstawowej - w nowicjacie oraz w czasie profesji czasowej. Prowadzenie dialogu jest obowiązkiem prawnym, weryfikowalnym w zakresie wewnętrznym i powinien skutkować także w życiu duchowym.

\section{PIŚMIENNICTWO}

Bilska, Maria. 2013. Obowiazek zamieszkania zakonnika we własnym domu zakonnym. Kraków: Wydawnictwo Homo Dei.

Chiappetta, Luigi. 2011. Il Codice di diritto canonico. Libri I-II. Wyd. 3. Bologna: Edizioni Dehoniale Bologna.

Dąbek, Tomasz. 2009. Wokót Reguty św. Benedykta. Kraków: Wydawnictwo Petrus.

Florek, Tadeusz. 2017. „Sprawowanie władzy w oparciu o dokument Młode wino, nowe bukłaki.” https://www.karmel.pl/sprawowanie-wladzy-w-oparciu-o-dokument-mlodewino-nowe-buklaki/ [dostęp: 10.05.2021].

Łukaszyk, Romuald. 1985. „Dialog.” W Encyklopedia Katolicka, t. 3, 1259-261. Lublin: Towarzystwo Naukowe KUL.

Rincón, Tomás. 2007. „Troisième Partie. Les instituts de la vie consacrée et les sociétiés de vie apostolique." W Code de droit canonique bilingue et annoté, wyd. 3, red. Ernest Caparros, Michel Thériault, Jean Thorn, i in., 853. Montreal: Wilson \& Lafleur Itée.

Szewczul, Bożena. 2010. „Ewangeliczna rada posłuszeństwa w posłudze przełożonego.” W Ewangeliczna Rada postuszeństwa $w$ życiu konsekrowanym zakonnym a wolność osoby, red. Wiesław Kiwior, Jan Krajczyński, i Henryk Stawniak, 65-85. Warszawa: Wydawnictwo UKSW. 
Zubert, Bronisław. 1990. Komentarz do Kodeksu Prawa Kanonicznego z 1983 r. T. 2. Cz. 3. Lublin: Redakcja Wydawnictw KUL.

\title{
Kanoniczno-prawne obszary dialogu w życiu zakonnym
}

\begin{abstract}
Abstrakt
Dialog w życiu zakonnym jest rzeczywistością wpisaną z życie zakonne. Życie wspólnotowe ma kilka istotnych obszarów i dotyczy relacji pomiędzy członkami danego instytutu oraz relacji pomiędzy członkami i przełożonymi. Dialog ten rozpoczyna się na etapie formacji nowicjackiej pomiędzy nowicjuszami i mistrzem nowicjuszy. Następnie jest kontynuowany na etapie profesji czasowej; wreszcie na etapie formacji ciągłej. Wszyscy są zobowiązani do życia wspólnotowego we wzajemnym zrozumieniu, które dokonuje się przez dialog. Także ważne decyzje w instytucie zakonnym dokonują się we wzajemnym dialogu. Instytucją, która reprezentuje cały instytut jest kapituła generalna, w której uczestniczą członkowie z urzędu i członkowie z wyboru. Pozostali członkowie instytutu mogą, zgodnie z prawem, zgłaszać swoje życzenia i sugestie. Decyzje na niej zapadają po dyskusji wymaganą większością głosów. Przełożeni podejmują decyzję z udziałem rady, która może mieć charakter wiążący lub doradczy. Można więc powiedzieć, że dialog w obszarze życia zakonnego ma swoje miejsce. Trzeba jednak zawsze pamiętać, że decyzja należy do kapituły bądź przełożonych. Także sprawujący posługę władzy powinni zadbać o wykonanie podjętych decyzji.
\end{abstract}

Słowa kluczowe: życie zakonne; wspólnota; dialog

\section{Canonical and Legal Areas of Dialogue in Religious Life}

\begin{abstract}
Dialog in religious life is part of daily reality. It encompasses relationships between members of the given institute with each other and with their superiors. This dialog begins in the first stages of formation between the novices and their novice master. It continues during the time of professing temporary vows and never ceases during the life formation process. All members are bound to the religious life in mutual respect and understanding, which occurs through dialog. Institution, which represents the entire religious congregation, is the general chapter. Both members holding an office and elected members may participate in such a chapter. All the other members of the institute may report their wishes and suggestions in accordance with the law. Decisions are made after the discussion by the required majority vote. Superiors on the other hand make their decisions with the participation of their council, whose voice may be binding or only advisory. In short, dialog has its place in the life of religious institutes. Nevertheless, it is necessary to remember that the final decision belongs to the chapter or superiors, which also are responsible for carrying out the undertaken decisions.
\end{abstract}

Keywords: religious life; community; dialogue 
Information about Author: Rev. DR. HABIL. AMBROŻY SKORUPA - Department of the History of Canon Law, General Norms, the Sacramental Law and the Law of Institutes of the Consecrate, Faculty of Law, Canon Law and Administration, The John Paul II Catholic University of Lublin; correspondence address: Al. Racławickie 14, 20-950 Lublin, Poland; e-mail: ambrozy.skorupa@kul.pl; https://orcid.org/00000002-1849-8420 